Rosalina, Eksistensi Hak Ulayat

Jurnal Sasi Vol.16. No.3 Bulan Juli - September 2010

\title{
EKSISTENSI HAK ULAYAT DI INDONESIA
}

\author{
Oleh : Rosalina
}

\begin{abstract}
Communal Land Rights is the right of the highest land tenure of indigenous people. Indigenous groups is a unity that has a specific area, have a legal entity, has the authority and has its own wealth. rights applicable exit and into the Communal Land. into force because the only alliance in the sense that all citizens can reap the rewards of the land and all plants and animals that hidupdalam fellowship area. The right of association was substantially restrict freedom of the citizen as an individual effort, for the sake of fellowship. Valid exit, because instead of the customary law community, in principle, not allowed to participate received his/ working the land which is the fellowship area concerned. Only with the permission of the fellowship as well as pay compensation outsiders can get a chance to participate and use communal land. Along with the development of life, then the use of communal land is not only used to meet together, but also members of the public are allowed to use some lands to be used to meet their individual needs. Individual mastery of this process continues for generations and is recognized by the indigenous people.
\end{abstract}

Keyword: existence, customary rights

\section{A. LATAR BELAKANG.}

Tanah merupakan sumber daya penting dan strategis karena menyangkut hajat hidup seluruh masyarakat Indonesia yang sangat mendasar, karena tanah memiliki karaakteristik yang bersifat multi dimensi, multi sektoral, multi disiplin dan memiliki kompleksitas yang tinggi.

Sejarah hukum pertanahan di Indonesia tidak terlepas dari hak ulayat. Jauh sebelum terciptanya UU No 5 Tahun 1960 tentang Peraturan Dasar Pokok-pokok Agraria (UUPA), masyarakat hukum kita telah mengenal hak ulayat. Hak ulayat sebagai hubungan hukum yang konkret, pada asal mulanya diciptakan oleh nenek moyang atau kekuatan gaib, pada waktu meninggalkan atau menganugerahkan tanahyang bersangkutan kepada orang-orang yang merupakan kelompok tertentu (Boedi Harsono, 1999).
Hak ulayat itu sendiri bagian yang tidak terpisahkan dari masyarakat hukum adat.

Bagi masyarakat hukum adat tanah itu mempunyai kedudukan yang sangat penting karena merupakan satu-satunya benda kekayaan yang bersifat tetap dalam keadaannya, bahkan lebih menguntungkan. Selain itu tanah merupakan tempat tinggal, tempat pencaharian, tempat penguburan, bahkan menurut kepercayaan mereka adalah tempat tinggal dayang-dayang pelindung persekutuan dan para leluhur persekutuan (Soerejo Wignjodipoero, dalam Aminuddin Salle 2007)

Pada garis besarnya pada masyarakat hukum adat terdapat 2 (dua) jenis hak atas tanah yaitu hak perseorangan dan hak persekutuan hukum atas tanah. Para anggotapersekutuan hukum berhak untuk mengambil hasil tumbuh-tumbuhan dan binatang liar dari tanah persekutuan hukum 
Rosalina, Eksistensi Hak Ulayat

tersebut. Selain itu mereka berhak mengadakan hubungan hukum tertentu dengan tanah serta semua isi yang ada di atas tanah persekutuan hukum sebagai objek (Aminuddin Salle, 2007)

Hukum tanah adat yang murni berkonsepsi komunalistik, yang mewujudkan semangat gotong royong dan kekeluargaan, yang diliputi suasana religius. Tanah merupakan tanah bersama kelompok teritorial atau genealogik. Hak-hak perorangan atas tanah secara langsung ataupun tidak langsung bersumber pada hak bersama tersebut. Oleh karena, itu biarpun sifatnya pribadi, dalam arti penggunaannya untuk kepentingan pribadi dan keluarganya, tetapi berbeda dengan hakhak dalam Hukum Tanah Barat, sejak kelahirannya sekaligus dalam dirinya sudah terkandung unsur kebersamaan. Sifat komunalistik menunjuk kepada adanya hak bersama para anggota masyarakat hukum adat atas tanah, yang dalam kepustakaan hukum disebut Hak Ulayat. (Boedi Harsono, 1999)

Seiring perkembangan zaman, pergerakan pola hidup dan corak produksi masyarakat Indonesia dari pola-pola atau corak-corak tradisional menuju ke pola atau corak yang modern mengakibatkan tergerusnya secara perlahan nilai-nilai yang terkandung dalam hak ulayat. Dewasa ini masyarakat tidak lagi mengedepankan kebersamaan tetapi cenderung untuk berpikir individualistik.

Saat ini meskipun Indonesia telah memiliki unifikasi hukum pertanahan yang berpuncak di UU No. 5 Tahun 1960 tentang Peraturan Dasar Pokok-Pokok Agraria (UUPA). Dengan adanya UUPA tersebut, tidak ada lagi dualisme hukum pertanahan, dimana hukum yang berlku didasarkan pada golongan masing-masing namun penting untuk diingat bahwa hukum adat dan termasuk pula didalamnya ada hak ulayat adalah merupakan dasa hukum Tanah Nasional. Olehnya itu adalah sesuatu yang sangat rasional untuk melihat dan mengkaji keberadaan hak ulayat dalam Hukum Positif Indonesia khususnya di bidang hukum pertanahan.

Dalam makalah ini akan disajikan bahasan mengenai hak ulayat dengan rumusan masalah sebagai berikut :

\section{Bagaimana eksistensi hak ulayat dalam hukum positif Indonesia?}

2. Bagaimana batasan-batasan hak ulayat dalam hukum pertanahan Indonesia?

\section{B. METODE PENULISAN}

Metode yang digunakan dalam penulisan adalah dengan menggunakan tipe penelitian hukum normatif, yakni mengkonsepsikan hukum sebagai norma, kaidah, asas, atau dogma-dogma, dengan menggunakan pendekatan perundangundangan atau Statute Approach ${ }^{1}$ yang dijelaskan secara deskriptif berdasarkan permasalahan dengan berbagai aturan-aturan hukum dan literatur, serta mencari suatu opini hukum tentang masalah yang menjadi objek permasalahan.

\section{PEMBAHASAN}

\section{Hak Milik Menurut Hukum Adat}

Dalam hubungannya dengan tanah, menurut hukum adat tertanam suatu kepercayaan bahwa bagi setiap kelompok masyarakat hukum adat, tersedia suatu lingkungan tanah sebagai pemberian dari sesuatu kekuatan gaibsebagai pendukung kehidupan kelompokdan para anggotanya sepanjang zaman. Artinya bukan hanya untuk kepentingan satu generasi melainkan untuk

Peter Mahmud Marzuki; Penelitian Hukum; Jakarta; Kencana Prenada Media Group; 2005; hal. 96 
Rosalina, Eksistensi Hak Ulayat

generasi berikutnya dari kelompok hukum adat tersebut. Lingkungan yang merupakan faktor pendukung kehidupan kelompok dan para anggotanya adalah kepunyaan bersama masyarakat hukum adat. Hak kepunyaan secara bersama disebut beschikkingrecht yang diterima dalam perundang-undangan sebagai hak ulayat yang merupakan hak atas penguasaan atas tanah yang tertinggal dari masyarakat hukum adat. Kelompok masyarakat adat ini merupakan kesatuan yang mempunyai wilayah tertentu, mempunyai kesatuan hukum, mempunyai penguasa dan mempunyai kekayaan tersendiri.

\section{Menurut Bushar Muhammad} (2002:104), hak ulayat berlaku keluar dan kedalam. Berlaku keluar, karena bukan warga masyarakat hukum pada prinsipnya tidak diperbolehkan turut mengenyam/ menggaraptanah yang merupakan wilayah persekutuan yang bersangkutan. Hanya dengan seizin persekutuan. Serta membayar ganti rugi orang luar dapat memperoleh kesempatan untuk ikut serta menggunakan hak ulayat. Berlaku kedalam, karena hanya persekutuan dalam arti seluruh warganya yang dapat memetik hasil dari tanah serta segala tumbuhan dan binatang yang hidup dalam wilayah persekutuan. Hak persekutuan itu pada hakikatnya membatasi kebebasan usaha para warga sebagai perorangan, demi kepentingan persekutuan.

Seiring dengan perkembangan kehidupan, maka penggunaan tanah ulayat tidak hanya digunakan untuk memenuhi kebutuhan masing-masing. Proses penguasaan individu ini terus berlangsung secara turun temurun dan diakui oleh masyarakat hukum adat. Selain dalam penggunaan tanah tersebut sesuai dengan peraturan yang berlaku maka anggota masyarakat lain harus menghormatinya dan tidak boleh mengganggunya. Apabila ditelantarkan dalam jangka waktu tertentu, atau diperlukan untuk kepentingan yang lebih luas, maka penguasa adat dapat menentukan peruntukan dan penggunaan selanjutnya.

Menurut Rustandi Ardiwilaga (1962 :47-48), bahwa lahirnya pemilikan tanah bagi individu umumnya diawali pembukaan tanah yang diberitahukan kepada kepala persekutuan hukum dan diberikan tanda bahwa tanda itu akan digarap. Tanda itu, merupakan tanda pelarangan sehingga hasil pohon, tanah ataupun kolam yang ada hanya untuk yang berkepentingan saja, orang lain tidak boleh menggunakan dan mengambil hasilnya. Bentuk usaha seperti ini bersifat sementara, merupakan hak memungut hasil (genotsrecht), setelah panen ditinggalkan dan menggarap tanah di tempat yang lain yang belum pernah dibuka. Walaupun hak memungut hasil hanya satu sampai dua musim saja, hal ini tidak menghilangkan hubungan antara penggarap dengan tiap-tiap ladangyang pernah digarap, biasanya setelah tiga tahun penggarap kembali ke ladang yang ditinggalkan sehingga hubungan ini dapat diwariskan ke anak cucunya. Ladang berpindang bersifat ladang milik. Dengan demikian hak milik diperoleh dengan pembukaan tanah, setelah lebih dulu dibuat tanda-tanda batasnya.

Dalam konsesi hak bersama, para anggota masyarakat diliputi suasana magis religius sebagai keyakinan bahwa tanah merupakan karunia dari Tuahan Yang maha Esa, karena itu mereka menyadari kewajibannya untuk menjaga, menggunakan, serta memelihara dengan baik sesuai dengan norma-norma sebagai kristalisasi nilai luhur kehidupan yang telah dibentuk dan dihormati dulu. Berdasarkan uraian diatas maka dapat disimpulkan bahwa mengenai proses lahirnya hak individu yang merupakan awal kepemilikan atas tanah menurut hukum adat, pada dasarnya meliputi unsur :

a. Penguasaan secara individu dan turun temurun

b. Penguasaan itu digunakan untuk memenuhi kebutuhan hidupnya 
Rosalina, Eksistensi Hak Ulayat

Jurnal Sasi Vol.16. No.3 Bulan Juli - September 2010

c. Pemanfaatan tanah dengan tetap memelihara keselarasan kepentingan individu dan masyarakat

d. Memperoleh pengakuan dari penguasa adat dan dihormati oleh tetangga berbatasan dan masyarakat adat lainnya

e. Penguasa adat mempunyai kewenangan mengatur peruntukan dan penguasaan tanah

f. Ada hubungan yang bersifat "magis religius" antara manusia dan tanah

\section{Pengertian Hak Ulayat}

UUPA tidak memberikan pengertian hak ulayat, kecuali menyebutkan yang dimaksud hak ulayat adalah apa yang di dalam perpustakaan hukum adat disebut "beschikkingsrecht" (penjelasan Pasal 3 UUPA).

Menurut Ter Haar (dalam Farida Patittingi) hak ulayat adalah hak untuk mengambil manfaat dari tanah, perairan, sungai, danau, perairan pantai,laut, tanamantanaman dan binatang yang ada di wilayah masyarakat hukum adat yang bersangkutan

Menurut Pasal 1 angka 4 RUU SDAgraria (dalam Farida Patittingi) hak ulayat adalah kewenangan masyarakat hukum adat untuk mengatur secara bersama-sama pemanfaatan tanah, perairan, tanaman serta binatangbinatang yang ada di wilayah masyarakat hukum yang bersangkutan, sepanjang tidak bertentangan dengan kepentingan nasional.

Farida Patittingi sendiri memberikan definisi Hak Ulayat adalah hak masyarakat hukum adat terhadap tanah dan perairan serta isinya yang ada di wilayahnya berupa wewenang menggunakan dan mengatur segala sesuatu yang berhubungan dengan tanah dan perairan serta lingkungan wilayahnya di bawah pimpinan kepala adat.

Sementara itu Boedi Harsono (1999) bahwa Hak Ulayat merupakan seperangkaian wewenang dan kewajiban suatu masyarakat hukum adat, yang berhubungan dengan tanah yang terletak dalam wilayahnya. Hak Ulayat merupakan pendukung utama penghidupan dan kehidupan masyarakat yang bersangkutan sepanjang masa.

Hak Ulayat adalah nama yang diberikan para ahli hukum pada lembaga hukum dan hubungan hukum konkret antara masyarakatmasyarakat hukum adat dengan tanah wilayahnya, yang disebut tanah ulayat. Hak Ulayat masyarakat hukum adat mempunyai unsur :

- Mengandung hak kepunyaan bersama atas tanah bersama anggota atau warganya, yang termasuk bidang hukum perdata.

- Mengandung unsur kewajiban mengelola, mengatur dan memimpin penguasaan, pemeliharaan, peruntukan dan penggunaannya, yang termasuk dalam hukum publik.

Menurut Maria Sumardjono, dapatlah dikatakan, bahwa kriteria penentu masih ada atau tidaknya hak ulayat, harus dilihat pada tiga hal, yaitu :

1. Adanya masyarakat hukum adat yang memenuhi ciri-ciri tertentu sebagai subjek hak ulayat

2. Adanya tanah/wilayah dengan batas-batas tertentu sebagai lebensraum yang merupakan obyek hak ulayat.

3. Adanya kewenangan masyarakat hukum adat untuk melakukan tindakan-tindakan tertentu.

\section{Hubungan Antara Hak Ulayat Dan Hak Perseorangan}

Sihombing (dalam Sri Susyanti Nur, 2005 :55) membagi hukum tanah adat dalam 2 jenis yaitu :

a. Hukum Tanah Adat Masa Lalu Ciri-ciri hukum adat masa lampau adalah tanah-tanah yang dimiliki dan dikuasai oleh seseorang dan atau sekelompok masyarakat adat yang memiliki dan 
Rosalina, Eksistensi Hak Ulayat

menguasai serta menggarap, mengerjakan secara tetap maupun berpindah-pindah sesuai dengan daerah, suku, dan budaya hukumnya, kemudian secara turun temurun masih berada di lokasi daerah tersebut, dan atau mempunyai tanda-tanda fisik berupa sawah, ladang, hutan dan simbol-simbol berupa makam, patung, rumah-rumah adat, dan bahasa daerah sesuai dengan daerah yang ada di Negara Republik Indonesia.

b. Hukum Tanah Adat Masa Kini

Ciri-ciri tanah hukum adat masa kini adalah tanah-tanah yang dimiliki oleh seseorang atau sekelompok masyarakat adat dan masyarakat di daerah pedesaanmaupun kawasan perkotaan. Sesuai dengan daerah suku dan budaya hukumnyakemudian secara turun temurun atau telah berpindah tangan kepada orang lain dan mempunyai bukti-bukti kepemilikan serta secara fisik dimiliki atau dikuasai sendiri dan atau dikuasai orang/badan hukum.

Oleh karena itu dapat dinyatakan bahwa hubungan antara Hak Ulayat dengan Hak milik Perorangan yakni semakin kuat hak ulayat, maka semakin lemah hak perorangan dan sebaliknya semakin lemah hak ulayat maka semakin kuat hak perorangan.

\section{Sistem Hak-Hak Penguasaan Atas Tanah (disadur dari Boedi Harsono, 1999:183)}

Dalam hukum adat hak penguasaan tanah yang tertinggi adalah hak ulayat, yang mengandung 2 (dua) unsur yang beraspek hukum keperdataan dan hukum publik. Subyek hak ulayat adalah masyarakat hukum adat, baik teritorial ataupun genealogik, sebagai bentuk bersama para warganya. Tanah hak ulayat adalah tanah bersama para warga masyarakat hukum adat yang bersangkutan.

Di bawah hak ulayat adalah Hak Kepala Adat dan para Tetua Adat, yang sebagai petugas masyarakat hukum adat berwenang mengelola, mengatur dan memimpin peruntukan, penguasaan, penggunaan dan pemeliharaan tanah bersama tersebut. Tugas kewenangan ini beraspek hukum publik semata.

Kemudian ada berbagai hak-hak atas tanah yang dikuasai oleh para warga masyarakat hukum adat yang bersangkutan, yang semuanya secara langsung ataupun tidak langsung bersumber pada hak ulayat sebagai hak bersama.

Dengan demikian tata susunan dan hirarki hak-hak penguasaan tanah dalam hukum adat adalah:

a. Hak ulayat masyarakat hukum adat, sebagai hak penguasaan tertinggi, beraspek hukum keperdataan dan hukum publik;

b. Hak kepala adat dan para tetua adat, yang bersumber pada hak ulayat dan beraspek hukum publik semata;

c. Hak-hak atas tanah sebagai hak-hak individual yang secara langsung ataupun tidak langsung bersumber pada hak ulayat dan beraspek hukum keperdataan.

\section{Eksistensi Hak Ulayat Dalam Hukum Positif Indonesia}

Gerakan reformasi yang di mulai pada tahun 1998 tidak hanya menghadirkan suatu kebaruan dalam bernegara dan bermasyarakat di Indonesia, tetapi juga menghidupkan kembali perdebatan lama ke dalam masa transisi. Konsep tentang hubungan negara dengan sumberdaya alam, atau hak masyarakat atas sumberdaya alam menguat pada tahap pewacanaan dan gerakan. Paket empat kali amandemen UUD 1945 (19992002) menjadi ruang dimana pertarungan ide berlangsung. Setidaknya ada dua komponen yang berkaitan dengan relasi antara masyarakat adat dengan sumberdaya alam (hak ulayat) serta relasi antara negara dengan 
Rosalina, Eksistensi Hak Ulayat

Jurnal Sasi Vol.16. No.3 Bulan Juli - September 2010

sumberdaya alam, yang mesti dilihat sebagai suatu keterkaitan. Keterkaitan itu beranjak dari asumsi bahwa "hak" merupakan tema yang bersifat formal, relasional dan diskretif.

Pengakuan terhadap masyarakat hukum adat dan hak-haknya dinyatakan dalam pasal 18B ayat 2 (amandemen kedua) menyebutkan bahwa "Negara mengakui dan menghormati kesatuan-kesatuan masyarakat hukum adat serta hak-hak tradisionalnya sepanjang masih hidup dan sesuai dengan perkembangan masyarakat dan prinsip Negara Kesatuan Republik Indonesia, yang diatur dalam Undang-undang". Dan juga pada pasal 28i ayat 3 (amandemen kedua) menyebutkan bahwa "Identitas budaya dan hak masyarakat tradisional dihormati selaras dengan perkembangan zaman dan peradaban".

Kemajuan terpenting dari pengakuan hak ulayat dalam Konstitusi di Indonesia ditemukan sebagai hasil amandemen kedua UUD 1945. Pasal 18B ayat 1 dan ayat 2 UUD 1945 menyebutkan :

(1). Negara mengakui dan menghormati satuan-satuan pemerintahan daerah yang bersifat khusus atau bersifat istimewa yang diatur dengan undang-undang.

(2). Negara mengakui dan menghormati kesatuan-kesatuan masyarakat hukum adat beserta hak-hak tradisionalnya sepanjang masih hidup dan sesuai dengan perkembangan masyarakat dan prinsip Negara Kesatuan Republik Indonesia, yang diatur dalam undangundang.

Maria S.W. Sumardjono menyebutkan bahwa eksistensi hak ulayat dalam hukum positif Indonesia dapat dilihat dalam peraturan-peraturan perundangan yang diterbitkan. Dalam Undang-undang Nomor 23 Tahun 1997 tentang Pengelolaan Lingkungan Hidup, Undang-undang Nomor 22 tentang Tenaga Listrik, Undang-undang Nomor 21 tentang Otonomi Khusus Papua, Undangundang Nomor 7 Tahun 2004 tentang Sumber Daya Air, Undang-undang Nomor 18 Tahun
2004 tentang Perkebunan, Undang-undang Nomor 38 Tahun 2004 tentang Jalan, Undangundang Nomor 31 Tahun 2004 tentang Perikanan, dan Undang-undang Nomor 41 Tahun 1999 tentang Kehutanan.

\section{Batasan-batasan Hak Ulayat Dalam Hukum Pertanahan Indonesia}

Ketentuan Pasal 18B ayat 1 dan ayat 2 memisahkan antara persoalan tata pemerintahan yang bersifat khusus dan istimewa yang diatur dengan UU (Pasal 18B ayat 1) dengan persoalan hak ulayat dan pembatasannya (Pasal 18 ayat 2). Selama ini, persoalan ulayat sering dikaitkan dengan hakhak atas sumberdaya alam yang ditarik dari sistem kerajaan pada masa lalu. Pemisahan antara Pasal 18B ayat 1 dengan Pasal 18B ayat 2 memberi arti penting untuk membedakan antara bentuk persekutuan masyarakat (hukum) adat dengan pemerintahan "kerajaan" lama yang masih hidup dan bersifat istimewa. Meski sudah mengakui dan menghormati keberadaan masyarakat hukum adat beserta hak ulayatnya secara deklaratif, Pasal 18B ayat 2 mencantelkan beberapa persyaratan yang harus dipenuhi suatu masyarakat untuk dapat dikategorikan sebagai masyarakat hukum adat beserta hak ulayat yang dapat dinikmatinya secara aman. Persyaratan-persyaratan itu secara kumulatif adalah:

a. Sepanjang masih hidup

b. Sesuai dengan perkembangan masyarakat

c. Sesuai dengan prinsip NKRI

d. Diatur dalam Undang-undang.

Rikardo Simarmata (dalam Arizona Yance) menyebutkan bahwa persyaratan terhadap masyarakat adat dan hak ulayatnya yang dilakukan oleh UUD 1945 pasca amandemen memiliki sejarah yang dapat dirunut dari masa kolonial. Aglemene Bepalingen (1848), Reglemen Regering (1854) dan Indische Staatregeling (1920 dan 
Rosalina, Eksistensi Hak Ulayat

1929) mengatakan bahwa orang pribumi dan timur asing yang tidak mau tunduk kepada hukum Perdata Eropa, diberlakukan undangundang agama, lembaga dan adat kebiasaan masyarakat, sepanjang tidak bertentangan dengan asas-asas yang diakui umum tentang keadilan. Persyaratan yang demikian bersifat diskriminatif karena terkait erat dengan eksistensi kebudayaan. Orientasi persyaratan yang muncul adalah upaya untuk menundukan hukum adat / lokal dan mencoba mengarahkannya menjadi hukum formal / positif / nasional. Di sisi lain juga memiliki pra anggapan bahwa masyarakat adat adalah komunitas yang akan "dihilangkan" untuk menjadi masyarakat yang modern, yang mengamalkan pola produksi, distribusi dan konsumsi ekonomi moderen.

Pengakuan bersyarat terhadap masyarakat adat dalam sejarah Republik Indonesia dimulai pada UUPA, UU kehutanan lama, UU Pengairan, UU Kehutanan baru dan beberapa Peraturan Departemen dan Lembaga Pemerintahan. Stelah UUD 1945 mengadopsi empat persyaratan bagi masyarakat adat, kemudian berbagai UU yang lahir pasca amandemen mengikuti alur tersebut, antara lain oleh UU Sumberdaya Air, UU Perikanan dan UU Perkebunan.

Pengakuan bersyarat ini mengindikasikan bahwa pemerintah masih belum bersungguhsungguh membuat ketentuan membuat ketentuan yang jelas untuk menghormati dan mengakui hak ulayat masyarakat hukum adat. Pengaturan tentang masyarakat adat dan hak ulayatnya sampai hari ini masih bersifat tidak jelas dan tidak tegas. Tidak jelas karena belum ada aturan yang konkret tentang apa saja hakhak yang terkait dengan keberadaan masyarakat yang dapat dinikmatinya. Dikatakan tidak tegas karena belum ada mekanisme penegakan yang dapat ditempuh dalam pemenuhan hak masyarakat adat, yang dapat dituntut dimuka pengadilan (Justiciable).
Ketidakjelasan dan ketidaktegasan itu terjadi dikarenakan dua hal, yaitu antara ketidakmampuan dan ketidak-mauan pemerintah membuat ketentuan yang umum tentang pengakuan (hak-hak) masyarakat adat. Tidak mampu karena persekutuan masyarakat adat di Indonesia sangat beragam berdasarkan sebaran pulau, system sosial, antropologis dan agama. Tidak mau karena pengaturan yang kabur tentang masyarakat memberikan ruang diskresi dan hegemoni kepada pemerintah untuk dapat memanipulasi hak-hak asli masyarakat demi kepentingan eksploitasi sumberdaya alam yang berada di wilayah masyarakat adat. Ketidakmauan ini menguntungkan penguasa dan merugikan masyarakat adat.

Persyaratan dalam Pasal 18B ayat 2 beserta dengan serangkaian persyaratan yang dilanjutkan oleh beberapa UU Sumberdaya Alam menunjukan bahwa Negara cq Pemerintah baru bisa mengakui dan menghormati hak ulayat masyarakat adat secara deklaratif, belum sampai pada tindakan hukum untuk melindungi dan memenuhi agar hak ulayat masyarakat adat dapat terpenuhi. Bahkan sama sekali belum menyentuh mekanisme penegakan hukum nasional bila terjadi pelanggaran terhadap hak ulayat yang sudah dianggap sebagai hak asasi manusia.

\section{P E N U T U P}

\section{Kesimpulan}

Eksistensi Hak Ulayat dalam hukum positif Indonesia masih ada. Hal demikian diakui dalam UUD NRI 1945 Pasal 18B ayat 1 dan ayat 2 serta dalam berbagai Undangundang.

Adapun batasan-batasan Hak Ulayat dalam Hukum Pertanahan Indonesia adalah bahwa Hak Ulayat tersebut sepanjang masih hidup, bahwa Hak Ulayat tersebut sesuai dengan perkembangan masyarakat, bahwa 
Rosalina, Eksistensi Hak Ulayat

keberadaan Hak Ulayat tersebut harus sesuai dengan prinsip NKRI, bahwa keberadaan Hak Ulayat tersebut harus diatur dalam Undangundang.

\section{Saran}

Keberadaan hak ulayat sebagai roh dari hukum pertanahan nasional tetap harus dijaga kelestariannya. Tentunya dengan menerapkan pembatasan-pembatasannya secara konsisten.

\section{DAFTAR PUSTAKA}

\section{Buku}

Arizona Yance, 2008, mengintip Hak Ulayat Dalam Konstitusi Indonesia.

B.F. Sihombing, 2005, Evolusi Kebijakan Pertanahan Dalam Hukum Tanah Indonesia, PT. Gunung Agung, Jakarta.

Bushar Muhammad, 2002, Pokok-pokok Hukum Adat, Pradnya Paramita, Jakarta.

Harsono Boedi, 1999, Hukum Agraria Indonesia, Sejarah Pembentukan Undang-undang Pokok Agraria, Isi dan Pelaksanaannya, Djambatan, Jakarta.

Rustandi Ardiwilaga, 1962, Hukum Agraria Indonesia, Masa Baru, Jakarta.

Salle Aminuddin, 2007, Hukum Pengadaan Tanah Untuk Kepentingan Umum, Kreasi Total Media, Yogyakarta.

Sumardjono Maria S W, Harmonisasi Kedudukan Hak Ulayat Dalam Peraturan Perundang-undangan di Indonesia.

\section{Lain-lain :}

Anonim, www.pengacaraonline.com, Hak Ulayat Dalam Hukum Agraria Indonesia.

Patittingi Farida, www.asdarfh .wordpress.

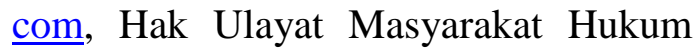
Adat. 